\title{
Implementation of Assessment Techniques At TK Pratama Kids Sukabumi Bandar Lampung
}

\author{
Lina Muliana \\ linamuliana98@gmail.com \\ Universitas Islam Negeri Raden Intan Lampung, Bandar Lampung \\ Heny Wulandari \\ jengheny9@gmail.com \\ Universitas Islam Negeri Raden Intan Lampung, Bandar Lampung \\ Agus Jatmiko \\ agusjatmiko@radenintan.ac.id \\ Universitas Islam Negeri Raden Intan Lampung, Bandar Lampung
}

\begin{abstract}
Assessment is for collecting, reporting, gathering information about student learning outcomes. In conducting the assessment, there are appropriate techniques for measuring child development. This research is a descriptive qualitative research involving teachers. Data were analyzed qualitatively by collecting data, displaying data and drawing conclusions. The conclusions obtained from several assessment techniques studied were based on a combination of several theories, the results showed that several assessment techniques had been fulfilled, including: the observation assessment technique for children's learning outcomes. however, there are also assessment techniques that are not carried out by teachers on a daily basis, such as the absence of anecdotal notes, children's development scales, and assessment of portfolios. Some of the assessment procedures carried out are formulating or defining activities, preparing assessment tools or techniques, define the assessment criteria, and determine the value. However, there is one procedure that has not been fulfilled, namely collecting data, educators are lacking in collecting data on children's learning outcomes. The principles of assessment in TK Pratama Kids Sukabumi Bandar Lampung, the teacher have carried out the principles of assessment such as carrying out a thorough, sustainable, oriented, objective, educating and sustainable way. However, there are several principles of assessment that have not been maximized, namely being objective when assessing students.
\end{abstract}

Keyword: Assessment, Techniques in Kindergarten, Pratama Kids

(C) 2021 Lina Muliana, Heny Wulandari, Agus Jatmiko

This work is licensed under a Creative Commons Attribution-ShareAlike

\section{INTRODUCTION}

The aim of assessment is to determine the degree to which learning goals have been met and to evaluate the efficacy of the teaching and learning process (Widiana 
2016). Teachers and parents play an important role in stimulating and understanding all facets of development, and children in early childhood learning have the ability to participate in a scientific learning process (Agus Jatmiko 2020). All people who are still in the midst of a rapid growth process that is necessary for the next stage of life. (Heny Wulandari 2018) Planning, executing, evaluating teaching effectiveness, and providing instruction are the four primary tasks of the instructor. Learning in the context of learning in early childhood education is an effort to collect, analyze and interpret various information about the performance and progress of various aspects of development that can be achieved by children after participating in habituation activities within a certain period of time (Haris 2013) A good learning process would be developed by good evaluation.

The nature of this methodology is crucial because it is a means of gathering data and assessing the progress of a learning process. Here are several evaluation methods used in the child assessment process: Observation, children's work, anecdotal notes, the developmental exhaustion scale, a portfolio, and reporting are all included in this analysis (Ifat Fatimah Zahro n.d.).

According to general rule of Ministry of National Education RI No. 23/2016 About Educational Assessment Standards chapter IV Po 5, the following are the principles of assessment of learning outcomes: valid, objective, fair, integrated, open, comprehensive and continuous, systematic, referenced (Kusaeri, Pendidikan 2013) Early childhood education evaluation procedures, according to Mulyasa, include formulating tasks, planning assessment instruments, defining assessment requirements, collecting data, and assigning grades (Ifat Fatimah Zahro n.d.)

According to the findings of interviews with researchers at TK Pratama Kids Sukabumi Badar Lampung, evaluation techniques in Kindergarten had used multiple assessment techniques, but there were still some that had not been used due to restricted facilities such as the lack of computers at school and teachers' knowledge of how to use technology. As a result, the evaluation is limited to findings, children's work, and written reports in the form of report cards.

Based on the above problems, the researchers are interested, want to know, discuss and study more deeply the Implementation of Assessment Techniques at TK Pratama Kids Sukamubi Bandar Lampung.

\section{METHODOLOGY}

This research uses a qualitative descriptive approach, according to Suharsimi, this research is called research that is what it is in a situation that is not manipulated by circumstances or conditions. Meanwhile, descriptive is an attempt to interpret the current condition or occur in other words to obtain information about the current state.

The research subjects were 2 class teachers who will be the research subjects, namely representatives of class B1 and B2, the object of this research is the implementation of the assessment technique at TK Pratama Kids Sukabumi Bandar Lampung, the research location at TK Pratama Kids Sukabumi Bandar Lampung, located on Jl. Tirtayasa No. 33 Sukabumi Bandan District, Lampung.

Data collection used was interviews, observation and documentation. Existing data were analyzed interactively, namely: reduction, data display and conclusion. The data validity techniques used were source triangulation, technical triangulation and time triagulation. 


\section{RESULTS AND DISCUSSION}

The researchers used evaluation methods in Kindergarten Pratama Kids based on the outcomes of interviews, observations, checklists, and documentation.

\section{Way out the Research Problem}

Based on the results of the writer's observations in the field at Kindergarten Pratama Kids, they compiled an assessment when planning the learning program in RPPH, the sub-themes to be implemented had been arranged and had already determined what assessment would be assessed.

Based on the results of observing observations in determining appropriate assessment techniques for child development, teachers need indicators that will be used in assessing children's development in TK Pratama Kids Sukabumi, Bandar Lampung. There are several stages of assessment that are not carried out by the teacher optimally at school every day, namely the absence of anecdotal notes, portfolios and child development scales.

Observations are observations that are carried out directly to obtain information data about the growth and development of students in various situations and activities carried out, so that the observation is more focused, Kindergarten Primary Kids teachers use observation instruments, using existing instruments, with reference to six aspects of achievement child development. Then the work process is carried out which means the work of students after carrying out an activity in the form of handwork or art, the children's work can be displayed in an independent form or in the form of an exhibition of children's work presented together. The implementation of the assessment of the work in Pratama Kids Kindergarten, which is carried out by the teacher, assesses the children's work after carrying out an activity that is given a grade and then put it together. The results of observations of the results of the kasrya were not maximally carried out, because the results of the work were made into one in the form of a portfolio. Furthermore, a developmental achievement scale is carried out, namely a checklist derived from the daily learning implementation plan (RPPH) which contains predetermined indicators of child development fatigue and these indicators have been listed in the RPPH. The categories of fatigue include: Not Developing (BB), Starting to Develop (MB), Developing As Expected (BSH), and Developing Very Well (BSB). The scale of children's development in Kindergarten Pratama Kids is not carried out by the teacher when the assessment process takes place every day. The next stage is carried out by implementing a portfolio assessment.

A portfolio is all data that has been collected while observing children, in the form of checklists, anecdotal notes and students' work. Each child must have a container that has been given an identity, the data set is sorted by event, the collection of all the information is called a portfolio. The portfolio format can be developed by each institution. The front cover contains photos and identities of the peseta students. content sheet contains: photos of children's activities, teacher notes about student activities (written while observing students), and basic competency analysis. Based on the results of interviews, portfolio assessment at TK Pratama Kidis was not used, because there were several assessment techniques that were not 
carried out in the learning process, because this portfolio assessment had to collect all data such as developmental achievement scales, anecdotal notes, and children's work.

Subsequently presented with reporting, reporting in the form of descriptions of physical growth and development of competence attitudes, knowledge, and skills of children. Reporting on learning outcomes in Kindergarten Pratama Kids uses report card assessments that are distributed at the end of each semester. The contents of the report describe the progress of the development of children who have reached BSH and BSB in each indicator on the basic competencies of the development program, and provide recommendations for parents to develop the abilities of children whose development indicators are still in $\mathrm{BB}$ and $\mathrm{MB}$.

In line with the results of the researchers' observations in drawing conclusions on child development, the teacher saw how the techniques were used in child development, then the teacher saw the developmental assessment standards that had been developed by the teacher from Permendikbud 137 and 147.This was done so that the results of the child's developmental learning were assessed. in accordance with what has been set. After that, the teacher determines or draws conclusions by giving an assessment on a scale of BB (not yet developing), MB (still developing), BSH (developing as expected). and BSB (very well developed).

This is supported by the results of an interview by the researcher with one of the Kindergarten Pratama Kids teachers who said that in implementing assessment standards in child development, determining standards or indicators that are in accordance with children's development, and adapting to the previously established techniques.

Table 1

Table of Observation Results of Assessment Techniques in Pratama Kids Kindergarten Sukabumi, Bandar Lampung

\begin{tabular}{|c|c|c|c|c|}
\hline \multirow[t]{2}{*}{ No } & \multirow{2}{*}{$\begin{array}{l}\text { Assessment } \\
\text { Techniques }\end{array}$} & \multirow[t]{2}{*}{ Deskriptif } & \multicolumn{2}{|l|}{ Score } \\
\hline & & & Yes & No \\
\hline 1. & Observation & $\begin{array}{l}\text { 1. The teacher formulates the } \\
\text { assessment in TK Pratama Kids } \\
\text { by creating an assessment } \\
\text { program that can be used for one } \\
\text { year. } \\
\text { 2. Teachers use all assessment } \\
\text { techniques }\end{array}$ & $\checkmark$ & \\
\hline 2. & Product & $\begin{array}{l}\text { The results of the students' work after } \\
\text { carrying out activities can be in the form } \\
\text { of handwork or works of art }\end{array}$ & $\checkmark$ & \\
\hline 3. & Anekdot Note & $\begin{array}{l}\text { Notes about the attitudes and behavior } \\
\text { of students that occur specifically or } \\
\text { events occur suddenly }\end{array}$ & & $\sqrt{ }$ \\
\hline 4. & $\begin{array}{l}\text { Developmental } \\
\text { fatigue scale }\end{array}$ & $\begin{array}{l}\text { Assessment is used as a daily } \\
\text { assessment in assessing progress by } \\
\text { group }\end{array}$ & & $\sqrt{ }$ \\
\hline 5. & Portofolio & $\begin{array}{l}\text { Collection of work learning outcomes of } \\
\text { students }\end{array}$ & & $\checkmark$ \\
\hline
\end{tabular}




\begin{tabular}{|l|l|l|c|c|}
\hline 6. & Report & $\begin{array}{l}\text { Reporting of learning outcomes using } \\
\text { report card assessments that are } \\
\text { distributed at the end of each semester }\end{array}$ & $\checkmark$ & \\
\hline
\end{tabular}

Based on the results of the Observation of Early Childhood Education Assessment Procedures at TK Pratama Kids Sukabumi Bandar Lampung

\section{Formulating Activities}

Researchers conducted observations on how to determine activities in Pratama Kids Kindergarten by making a semester programe or so called Program semester/PROMES, up to the daily implementation plan or so callaed Rencana Pelaksanaan Harian/RPPH which can be used for one year. In the daily implementation plan, there are indicators that want to be achieved and assessed and involve all six aspects of development in early childhood, namely moral religious development, cognitive development, motor development, social emotional development, language development, and art development.

\section{Setting Up Assessment Tools}

Researchers observed that in preparing appropriate assessment tools for child development, teachers needed indicators that would be used in assessing early childhood development in Prtama Kids Kindergarten. There are several stages of assessment that are not carried out by school teachers on a daily basis, namely the absence of anecdotal notes, portfolios and developmental fatigue scales.

\section{Establish Assessment Criteria}

After determining the technique or tool to be used, the next step is to determine the criteria for assessment. Teachers in Pratama Kids Kindergarten use observation instruments, either those developed by the teacher themselves or using existing instruments, while still referring to 6 aspects of indicators of children's development achievement.

\section{Data collection}

At TK Pratama Kids Sukabumi Bandar Lampung, data is not collected, and educators do not collect all of the work of students in the given folders. When the work of the students has been ranked as a star, the teacher returns it to the students' house. In the mean time, educators will find out the success of their students from the achievement of work through a list of student's work included in the binding, as proof of the outcomes of previous learning activities.

\section{Value assessment}

The instructor will manage and draw conclusions from the outcomes of the assessment based on information received, in order that they finally gain an image of the child's growth and development or other aspects of learning that has been carried out. The instructor documents it in the student's report after management and explanation occur. The reporting activity is an activity to clarify teacher evaluation outcomes in relation to student growth and development. The aim is to provide parents or guardians with insight into their children's growth and development in school. 
The form of reporting at TK Pratama Kids Sukabumi Bandar Lampung is in the form of checklist assessment and description. Furthermore, educators can make decisions that are considered necessary as follow-up materials.

Table 2

Observation Sheet of Early Childhood Education Assessment Procedure at TK Pratama Kids Sukabumi Bandar Lampung

\begin{tabular}{|c|c|c|c|c|}
\hline \multirow[t]{2}{*}{ No } & \multirow{2}{*}{$\begin{array}{l}\text { Assessment } \\
\text { Procedures }\end{array}$} & \multirow[t]{2}{*}{ Deskriptif } & \multicolumn{2}{|l|}{ Score } \\
\hline & & & Yes & No \\
\hline 1. & $\begin{array}{l}\text { Formulating } \\
\text { Activities }\end{array}$ & $\begin{array}{l}\text { 1. Teachers prepare a semester } \\
\text { programe or so called Program } \\
\text { semester/PROMES. } \\
\text { 2. Teacher prepares The Weekly } \\
\text { implementation Plan or so called } \\
\text { rencana pelaksanaan pembelajaran } \\
\text { mingguan/RPPM. } \\
\text { 3. Teachers prepare The Daily } \\
\text { Implementation plan or so callaed } \\
\text { Rencana Pelaksanaan Harian/RPPH. }\end{array}$ & $\checkmark$ & \\
\hline 2. & $\begin{array}{l}\text { Setting Up } \\
\text { Assessment } \\
\text { Tools }\end{array}$ & $\begin{array}{l}\text { The teacher prepares an assessment } \\
\text { tool that has been set for use in } \\
\text { program implementation activities. } \\
\text { Teachers can make their own, can also } \\
\text { use existing tools that are used } \\
\text { according to The Daily Implementation } \\
\text { plan or so callaed Rencana Pelaksanaan } \\
\text { Harian/RPPH. }\end{array}$ & $\checkmark$ & \\
\hline 3. & $\begin{array}{l}\text { Establish } \\
\text { Assessment } \\
\text { Criteria }\end{array}$ & $\begin{array}{l}\text { The teacher sets the assessment criteria. } \\
\text { The assessment criteria is a measure of } \\
\text { the child's success. The benchmark is } \\
\text { used to determine the child's score. }\end{array}$ & $\checkmark$ & \\
\hline 4. & $\begin{array}{l}\text { Data } \\
\text { collection }\end{array}$ & $\begin{array}{l}\text { The tool that has been completed by } \\
\text { the teacher is used to retrieve data } \\
\text { related to the ability to be assessed } \\
\text { from the child. }\end{array}$ & & $\checkmark$ \\
\hline 5. & $\begin{array}{l}\text { Value } \\
\text { assessment }\end{array}$ & $\begin{array}{l}\text { The teacher describes or provides } \\
\text { conclusions from the results of the } \\
\text { evaluation, After processing and } \\
\text { description, the educator records it in } \\
\text { the children's education report. }\end{array}$ & $\checkmark$ & \\
\hline
\end{tabular}

Based on the results of research observations on the principles of assessment in Pratama Kids Kindergarten

\section{Overall}

In determining the student's evolution from starting learning up to ending learning, teachers should observe how students evolve openly outside learning practices, even in cases of breaks. The instructor uses this concept in general. Free or 
natural play is an early childhood feature. Since the evaluation is performed without any pressure naturally, it is a successful evaluation because the students explain their actual situation.

TK Pratama Kids Sukabumi Bandar Lampung outcomes of observations, teachers test children in a classroom only and teachers evaluate students at the end of learning.

\section{Principles of Sustainability}

The principle of sustainability is carried out by the teacher when the teacher plans the assessment. the principle of sustainability means that the assessment of the achievement of students' development must be carried out in a planned, gradual and continuous manner to obtain a picture of the growth and development of children. By implementing this principle, an overview of the results of the assessment of the growth and development of students will be drawn continuously. The results of observations at TK Pratama Kids Sukabumi Bandar Lampung, teachers have implemented but not maximally there are several learning activities that are not in accordance with the assessment technique.

\section{Principle oriented}

The process-oriented and goal-oriented principle is carried out by the teacher when assessing the growth and development of students during the learning process by observing and recording each student's growth and development. From the notes that teachers have every day, the teacher can monitor the growth and development of each student properly. The assessment activities carried out by the teacher are in accordance with the learning objectives. All assessments are made based on learning objectives. The trick is to determine the learning indicators first then create learning activities that are in accordance with the indicators, from the learning activities learning objectives will emerge. Based on the activities and learning objectives, the teacher can determine the assessment tools that will be used to assess students.

\section{Objective Principles}

Objective assessment is an assessment that can provide actual or near true information about the object of ability or changes in growth and development experienced by the child. The objective principle is carried out by the teacher when the teacher records all the growth and development of students as they are without discriminating, because basically each student has a different background.

The results of observations at Kindergarten Pratama Kids Sukabumi Bandar Lampung, the objective principle has not been implemented optimally, because when assessing students the teacher disguises the child's grades, because when the assessment takes place online the teacher is difficult to judge if there is signal interference.

\section{Principles of Educating}

The results of the assessment must be able to foster and encourage the emergence of students 'desire to increase their growth and development. The process and results of developmental assessments must be able to make a positive contribution to improving the achievement of students' development. The process and results of the assessment can be used as a basis for motivating, developing, and 
fostering students to grow and develop optimally (can provide feedback and motivation).

The results of an interview with one of the teachers at TK Pratama Kids Sukabumi Bandar Lampung, the principle of educating has been applied, when children have difficulties the teacher helps and motivates students.

\section{The Principle of Mortality}

The principle of meaningfulness means that the teacher is also able to describe the child's growth and development specifically, clearly, and concretely of every growth and development that each child has. The results of the assessment must have meaning for parents, students, and other parties with an interest in the growth and development of children, at TK Pratama Kids Sukabumi Bandar Lampung, the principle of sustainability has been implemented, in the form of reporting every semester the teacher distributes report cards to guardians and also provides information. about child growth and development.

\section{Table 3}

Observation Sheet of Assessment Principles at TK Pratama Kids Sukabumi, Bandar Lampung

\begin{tabular}{|c|c|c|c|c|}
\hline \multirow[t]{2}{*}{ No } & \multirow{2}{*}{$\begin{array}{l}\text { Assessment } \\
\text { Techniques }\end{array}$} & \multirow[t]{2}{*}{ Deskriptif } & \multicolumn{2}{|l|}{ Score } \\
\hline & & & Ye & No \\
\hline 1. & Overall & $\begin{array}{l}\text { The overall principle means that the } \\
\text { assessment includes all aspects of child } \\
\text { development, both moral and religious } \\
\text { values, social-emotional, cognitive, } \\
\text { physical motor, art and language. }\end{array}$ & $\checkmark$ & \\
\hline 2. & $\begin{array}{l}\text { Principles of } \\
\text { Sustainability }\end{array}$ & $\begin{array}{l}\text { The teacher when assessing the } \\
\text { achievement of students' development } \\
\text { must be carried out in a planned, } \\
\text { gradual and continuous manner to } \\
\text { obtain a picture of the child's growth } \\
\text { and development. }\end{array}$ & $\checkmark$ & \\
\hline 3. & $\begin{array}{l}\text { Principle } \\
\text { oriented }\end{array}$ & $\begin{array}{l}\text { The teacher makes a daily learning } \\
\text { plan that contains learning indicators, } \\
\text { learning activities, learning objectives }\end{array}$ & $\checkmark$ & \\
\hline 4. & $\begin{array}{l}\text { Objective } \\
\text { Principles }\end{array}$ & $\begin{array}{l}\text { The teacher when judging by what it is } \\
\text { without discriminating, }\end{array}$ & & $\checkmark$ \\
\hline 5. & $\begin{array}{l}\text { Principles of } \\
\text { Educating }\end{array}$ & $\begin{array}{l}\text { Teachers encourage children towards } \\
\text { optimal development, } \\
\text { motivation }\end{array}$ & $\checkmark$ & \\
\hline 6. & $\begin{array}{l}\text { The Principle of } \\
\text { Mortality }\end{array}$ & $\begin{array}{l}\text { Teachers provide knowledge about } \\
\text { children's growth and development to } \\
\text { parents. }\end{array}$ & $\checkmark$ & \\
\hline
\end{tabular}

\section{CONCLUSION}

Based on the results of the previous research and discussion, the researchers concluded that the implementation of the assessment technique at TK Pratama Kids 
Sukabumi Bandar Lampung was from several indicators in the design of the assessment technique, there were several techniques that had been fulfilled, including: How to formulate an assessment, the assessment technique used, observation techniques during the learning process, have an assessment of children's work, reporting of children's learning outcomes, assessment standards. However, there are also assessment techniques that teachers do not perform on a daily basis, such as the absence of anecdotal notes, scale of child development achievement, and portfolio assessment.

The assessment technique has an assessment procedure that must be applied when assessing the growth and development of children in TK Pratama Kids Sukabumi Bandar Lampung which is studied based on a combination of several predetermined theories, including: 1) Formulating activities, 2) Preparing assessment tools, 3) Establishing criteria assessment 4) Collect data, 5) Determine the value. That is, in implementing the assessment procedure, educators do not implement it in accordance with existing procedures. Educators only carry out four of the five existing indicators, including formulating or defining activities, preparing assessment tools, establishing assessment criteria, and determining grades.

The assessment technique has assessment principles that must be applied when assessing the growth and development of children at TK Pratama Kids Sukabumi Bandar Lampung which is studied based on a combination of several predetermined theories, including: 1) Overall, 2) Sustainable, 3) Oriented principles, 4) Objective Principles, 5) Educating Principles, 6) and Fundamental Principles. The condition of the field at TK Pratama Kids Sukabumi Badar Lampung has applied the principles of assessment but it has not been implemented optimally. There is one principle of assessment that has not been implemented, namely the objective principle.

\section{ACKNOWLEDGEMENT}

Thank you to all the foundation, principals, and teachers board of TK Pratama Kids Sukabumi Bandar Lampung who have supported and allowed to carry out our research. Not to forget also we would like to thank JCD: journal of childhood development for publishing our research in the journal.

\section{REFERENCES}

Agus Jatmiko. 2020. "Penerapan Evaluasi Pembelajaran Anak Usia Dini Universitas Islam Negeri Raden Intan Lampung, Bandar Lampung, Indonesia Begitu Pentingnya Pendidikan Anak Usia Dini Dalam Pengelolaan Pendidikan Masyarakat, Hingga Di Dunia Internasional Melihat Bahwa Sala." 3(1):83-97.

Haris, Asep jihad \&.Abdul. 2013. Evaluasi Pembelajaran. yogyakarta: multi presindo.

Heny Wulandari. 2018. "Evaluation of Holistic Integrative Program in Early Childhood Education and." 3(June).

Ifat Fatimah Zahro. n.d. "Penilaian Dalam Pembelajaran Anak Usia Dini.” 1(1):92-111.

Kusaeri, Pendidikan, Inovasi. 2013. "Jurnal Inovasi Pendidikan."

Mardalis. 2004. Metode Penelitian Suatu Pendekatan Proposal. Jakarta: Bumi Aksara. 
Mulyasa. 2016. Menejemen PAUD. Bandung: Remaja Rosdakarya.

Pendidikan, Menteri, D. A. N. Kebudayaan, and Republik Indonesia. 2016. "Peraturan Mentri Pendidikan Dan Kebudayaan Republik Indonesia Nomor 23 Tahun 2016 Tentang Setandar Penilaian Pendidikan."

Suharsimi Arikunto. 2012. Prosedur Penelitian. Jakarta: Ranika Cipta.

Widiana, I.Wayan. 2016. "Pengembangan Asesmen Proyek Dalam Pembelajaran Ipa Di Sekolah Dasar." 5(2):147-57. 